\title{
Bile components and lecithin supplemented to plant based diets do not diminish diet related intestinal inflammation in Atlantic salmon
}

Trond M. Kortner ${ }^{1 *}$, Michael H. Penn ${ }^{1,4}$, Ingemar Björkhem², Kjell Måsøval ${ }^{3}$ and Åshild Krogdahl ${ }^{1}$

\begin{abstract}
Background: The present study was undertaken to gain knowledge on the role of bile components and lecithin on development of aberrations in digestive functions which seemingly have increased in Atlantic salmon in parallel with the increased use of plant ingredients in fish feed. Post smolt Atlantic salmon were fed for 77 days one of three basal diets: a high fish meal diet (HFM), a low fishmeal diet (LFM), or a diet with high protein soybean meal (HPS). Five additional diets were made from the LFM diet by supplementing with: purified taurocholate (1.8\%), bovine bile salt $(1.8 \%)$, taurine $(0.4 \%)$, lecithin $(1.5 \%)$, or a mix of supplements (suppl mix) containing taurocholate $(1.8 \%)$, cholesterol $(1.5 \%)$ and lecithin $(0.4 \%)$. Two additional diets were made from the HPS diet by supplementing with: bovine bile salt (1.8\%) or the suppl mix. Body and intestinal weights were recorded, and blood, bile, intestinal tissues and digesta were sampled for evaluation of growth, nutrient metabolism and intestinal structure and function.

Results: In comparison with fish fed the HFM diet fish fed the LFM and HPS diets grew less and showed reduced plasma bile salt and cholesterol levels. Histological examination of the distal intestine showed signs of enteritis in both LFM and HPS diet groups, though more pronounced in the HPS diet group. The HPS diet reduced digesta dry matter and capacity of leucine amino peptidase in the distal intestine. None of the dietary supplements improved endpoints regarding fish performance, gut function or inflammation in the distal intestine. Some endpoints rather indicated negative effects.
\end{abstract}

Conclusions: Dietary supplementation with bile components or lecithin in general did not improve endpoints regarding performance or gut health in Atlantic salmon, in clear contrast to what has been previously reported for rainbow trout. Follow-up studies are needed to clarify if lower levels of bile salts and cholesterol may give different and beneficial effects, or if other supplements, and other combinations of supplements might prevent or ameliorate inflammation in the distal intestine.

Keywords: Gut health, Intestinal inflammation, Fish feed, Plant ingredients, Cholesterol, Bile

\footnotetext{
* Correspondence: trond.kortner@nmbu.no

${ }^{1}$ Department of Basic Sciences and Aquatic Medicine, Faculty of Veterinary

Medicine and Biosciences, Norwegian University of Life Sciences, Oslo,

Norway

Full list of author information is available at the end of the article
} 


\section{Background}

Levels of plant protein ingredients in feeds for salmonids and several other cultivated species have gradually increased over the last two decades, replacing fish meal. Substitution of marine with plant protein in feed for carnivorous fish, especially when using less refined plant protein sources such as full-fat or extracted soybean meal (SBM), will in many cases result in reduced body pools of cholesterol and bile acids [1-6]. In severe cases, the reduced levels of cholesterol and bile acids may be observed in concert with reduced fish growth and gastro-intestinal problems such as intestinal inflammation and steatosis [2, 7]. These conditions may be related to, or influenced by reduced levels of cholesterol and bile components, or disturbances in lipid digestion and metabolism. The apparent drain of bile acids in Atlantic salmon suffering from SBM-induced enteritis (SBMIE) $[2,3,8,9]$ is likely caused by a combination of the reduced dietary cholesterol load and specific action of soy antinutrients such as saponins, which may impair cholesterol and bile acid uptake from the intestinal lumen [10-13].

Recent reports suggest that bile salts, in addition to their key role in lipid digestion, have important anti-inflammatory effects in the gut, and can preserve the intestinal barrier in inflammatory bowel disease (IBD) models [14-17]. Similarly, studies with rainbow trout indicate that dietary inclusion of bile salts or soybean lecithin may prevent distal intestinal inflammation induced by SBM or plant antinutrients $[5,18,19]$. In Atlantic salmon, the SBMIE has been established as an excellent and reproducible intestinal inflammation model, and the Atlantic salmon is more susceptible to SBMIE than the rainbow trout. However, it has not yet been investigated if supplementation with bile components or lecithin can prevent or reduce diet related intestinal inflammation in Atlantic salmon.

The work presented here is part of a larger experimental series with the main objective to develop knowledge needed to produce sustainable, healthy and cost efficient fish feeds with low fish meal inclusion, based on plant and other alternative nutrient sources, and to identify indicators of feed related health effects. Specifically, the present study aimed at increasing knowledge on relationships between plant induced intestinal inflammation and deficiencies of bile components in Atlantic salmon. Based on the above mentioned studies in rainbow trout, we hypothesized that dietary supplementation with bile components or lecithin to plant protein based diets would improve performance and gut health in Atlantic salmon. For that purpose, a 77 day feeding trial was conducted. At termination of the feeding trial, the weights of body and intestines were recorded, and blood, bile, intestinal tissues and digesta were sampled for evaluation of effects on growth, nutrient metabolism and intestinal structure (histomorphological changes) and function (digestive enzyme activities and faecal dry matter).

\section{Methods}

Experimental animals, diet and sampling

Atlantic salmon (Salmo salar L.) post smolts of the Sunndalsøra breed with mean weight of $362 \pm 95 \mathrm{~g}$ (mean $\pm \mathrm{SD}$ ) were weighed, pit tagged and randomly allocated into 20 cylindrical fiberglass tanks (200 L, 35 fish pr tank) with flow-through seawater $\left(6-7 \mathrm{~L} \mathrm{~min}^{-1}\right)$. Two replicate tanks per diet were used. Water temperature varied between 7 and $14{ }^{\circ} \mathrm{C}$. Oxygen content and salinity of the outlet water were monitored to ensure saturation above $85 \%$ and stability, respectively. A $24 \mathrm{~h}$ lighting regime was employed during the experimental period. The fish were weighed individually when allocating the fish to the experimental units to assure similar biomass in all tanks.

Ten experimental diets were formulated (Table 1). A fish meal based diet (high fish meal; HFM) was used as a control. A low fish meal (LFM) combination of soy protein concentrate (SPC) and pea protein concentrate, or high protein soya (HPS) provided the bulk of dietary protein in the two other diets. Conjugated bile salts, taurine, lecithin and cholesterol were added to these diets singly or in combination as described in Table 1. Supplementation levels were based on levels used in rainbow trout as previously reported [5, 18, 19]. Feed intake was not recorded. Diets were formulated to contain $41 \%$ crude protein and $30 \%$ lipid (DM basis). They were supplemented with a standard vitamin and micro-mineral premix and limiting essential amino acids (lysine, methionine) as necessary to provide required amounts as suggested by NRC guidelines [20]. Diets also contained $100 \mathrm{mg} \mathrm{kg-1}$ yttrium oxide as an inert marker for calculation of nutrient apparent digestibilities. Chemical analysis of the diets is shown in Table 1. Feed was produced by extrusion at the BioMar AS production facility in Brande, Denmark. Diets were extruded with a feed pellet size of $6 \mathrm{~mm}$.

The feeding trial ran for 77 days. Tank sampling order and fish sampling were conducted randomly. Fifteen fish were sampled from each tank and euthanized by anaesthetization with tricaine methane-sulfonate (MS-222) followed by a sharp blow to the head. From ten fish per tank, blood was sampled by venipuncture of the caudal vein. Blood was collected in Vacutainers containing lithium heparin and stored on ice until centrifugation. Plasma was separated and immediately frozen in liquid nitrogen and stored at $-80{ }^{\circ} \mathrm{C}$ until analysis. After blood withdrawal, fish were dissected to remove the viscera. Intestinal contents (digesta) were collected from the pyloric, mid and distal intestines. The contents from the pyloric intestines were 
Table 1 Diet formulation and chemical analysis

\begin{tabular}{|c|c|c|c|c|c|c|c|c|c|c|}
\hline & HFM & LFM & $\begin{array}{l}\text { LFM + } \\
\text { Tauro-cholate }\end{array}$ & $\begin{array}{l}\text { LFM + } \\
\text { Bovine bile salt }\end{array}$ & $\begin{array}{l}\text { LFM + } \\
\text { Taurine }\end{array}$ & $\begin{array}{l}\text { LFM + } \\
\text { Lecithin }\end{array}$ & $\begin{array}{l}\text { LFM + } \\
\text { Suppl Mix }\end{array}$ & HPS & $\begin{array}{l}\text { HPS + } \\
\text { Bovine bile salt }\end{array}$ & $\begin{array}{l}\text { HPS + } \\
\text { Suppl Mix }\end{array}$ \\
\hline \multicolumn{11}{|l|}{ Ingredient (g $100 \mathrm{~g}^{-1}$ ) } \\
\hline SA SP Sara Rousing ${ }^{a}$ & 15.00 & 5.00 & 5.00 & 5.00 & 5.00 & 5.00 & 5.00 & 7.50 & 7.50 & 7.50 \\
\hline Nordic LT 94 fishmeal ${ }^{\mathrm{b}}$ & 15.00 & 5.00 & 5.00 & 5.00 & 5.00 & 5.00 & 5.00 & 7.50 & 7.50 & 7.50 \\
\hline Soya HP $48^{\mathrm{C}}$ & & & & & & & & 20.00 & 20.00 & 20.00 \\
\hline Soya $60 \%(S P C)^{d}$ & 10.00 & 19.03 & 19.03 & 19.03 & 19.03 & 19.03 & 19.03 & 3.52 & 3.52 & 3.52 \\
\hline Corn Gluten ${ }^{\mathrm{e}}$ & 5.34 & 15.00 & 15.00 & 15.00 & 15.00 & 15.00 & 15.00 & 10.19 & 10.19 & 10.19 \\
\hline Pea Protein $50^{f}$ & 6.00 & 13.00 & 13.00 & 13.00 & 13.00 & 13.00 & 13.00 & 0.40 & 0.40 & 0.40 \\
\hline Dehulled Beans ${ }^{9}$ & 14.58 & 14.00 & 14.00 & 14.00 & 14.00 & 14.00 & 14.00 & 14.00 & 14.00 & 14.00 \\
\hline Sunflower expeller ${ }^{h}$ & 10.00 & & & & & & & & & \\
\hline Wheat Gluten ${ }^{i}$ & & 1.97 & 1.97 & 1.97 & 1.97 & 1.97 & 1.97 & 10.00 & 10.00 & 10.00 \\
\hline Fishoil (Standard) $)^{j}$ & 7.45 & 7.67 & 7.67 & 7.67 & 7.67 & 7.67 & 7.67 & 7.82 & 7.82 & 7.82 \\
\hline Rapeseed oil ${ }^{k}$ & 17.09 & 17.60 & 17.60 & 17.60 & 17.60 & 17.60 & 17.60 & 17.94 & 17.94 & 17.94 \\
\hline Sodium taurocholate & & & 1.80 & & & & & & & \\
\hline Bovine bile salt! & & & & 1.80 & & & 1.80 & & 1.80 & 1.80 \\
\hline Cholesterol' & & & & & & & 1.50 & & & 1.50 \\
\hline Taurine' & & & & & 0.40 & & & & & \\
\hline Lecithin' & & & & & & 1.50 & 0.40 & & & 0.40 \\
\hline MCP & 0.70 & 1.82 & 1.82 & 1.82 & 1.82 & 1.82 & 1.82 & 1.56 & 1.56 & 1.56 \\
\hline Lysine & 0.20 & 0.81 & 0.81 & 0.81 & 0.81 & 0.81 & 0.81 & 0.98 & 0.98 & 0.98 \\
\hline Methionine & 0.11 & 0.32 & 0.32 & 0.32 & 0.32 & 0.32 & 0.32 & 0.25 & 0.25 & 0.25 \\
\hline Threonine & & 0.11 & 0.11 & 0.11 & 0.11 & 0.11 & 0.11 & 0.14 & 0.14 & 0.14 \\
\hline Barox (antioxidant) & 0.03 & 0.03 & 0.03 & 0.03 & 0.03 & 0.03 & 0.03 & 0.03 & 0.03 & 0.03 \\
\hline Vitamin-Mineral mix ${ }^{m}$ & 0.30 & 0.30 & 0.30 & 0.30 & 0.30 & 0.30 & 0.30 & 0.30 & 0.30 & 0.30 \\
\hline Yttrium $^{n}$ & 0.05 & 0.05 & 0.05 & 0.05 & 0.05 & 0.05 & 0.05 & 0.05 & 0.05 & 0.05 \\
\hline Lucantin Pink CWD $10 \%$ & 0.04 & 0.04 & 0.04 & 0.04 & 0.04 & 0.04 & 0.04 & 0.04 & 0.04 & 0.04 \\
\hline \multicolumn{11}{|l|}{ Chemical analysis $^{\circ}$} \\
\hline Dry matter (\%) & 95.0 & 95.0 & 95.0 & 95.0 & 95.0 & 95.0 & 95.0 & 95.0 & 95.0 & 95.0 \\
\hline Ash (\%) & 7.0 & 5.0 & 5.0 & 5.0 & 5.0 & 5.0 & 5.0 & 5.2 & 5.2 & 5.2 \\
\hline Fat (\%) & 29.8 & 29.2 & 29.2 & 29.2 & 29.2 & 29.2 & 29.2 & 29.6 & 29.6 & 29.6 \\
\hline Protein (\%) & 40.8 & 40.4 & 40.4 & 40.4 & 40.4 & 40.4 & 40.4 & 41.4 & 41.4 & 41.4 \\
\hline D Protein (\%) & 36.0 & 36.0 & 36.0 & 36.0 & 36.0 & 36.0 & 36.0 & 36.0 & 36.0 & 36.0 \\
\hline DE (MJ/kg) & 20.3 & 20.3 & 20.3 & 20.3 & 20.3 & 20.3 & 20.3 & 20.3 & 20.3 & 20.3 \\
\hline GE (MJ/kg) & 24.4 & 24.4 & 24.4 & 24.4 & 24.4 & 24.4 & 24.4 & 24.6 & 24.6 & 24.6 \\
\hline Cholesterol (g/kg) & 2.1 & 0.8 & 0.7 & 0.6 & 0.7 & 0.7 & 19.1 & 1.0 & 1.0 & 17.8 \\
\hline Bile salts (g/kg) & 0.3 & 0.2 & 16.3 & $\mathrm{n} / \mathrm{a}$ & $\mathrm{n} / \mathrm{a}$ & $\mathrm{n} / \mathrm{a}$ & 11.0 & $\mathrm{n} / \mathrm{a}$ & 10.58 & $\mathrm{n} / \mathrm{a}$ \\
\hline
\end{tabular}

a Superprime, supplied by Köster Marine Proteins $\mathrm{GmbH}$, Hamburg, Germany

${ }^{\text {b}}$ Supplied by Norsildmel AS, Bergen, Norway

'Supplied by Scan Mills, Germany

${ }^{\mathrm{d}}$ Supplied by Selecta S/A, Av. Jamel Ceilio, 2496 - 12th region, Goiania, Brazil

eSupplied by Cargil Nordic, SAS van Gent, Holland

${ }^{f}$ Supplied by DLG Food Grain, Roslev, Denmark

'Supplied by HC Handelscenter, Skibby, Denmark

hupplied by DLA agro, Denmark

'Supplied by Roquette, Beinheim, France

'Supplied by FF Skagen, Skagen, Denmark

${ }^{\mathrm{k}}$ Supplied by Emmelev, Otterup, Denmark

'Supplied by Sigma-Aldrich, Broendby, Denmark

${ }^{m}$ Supplied to meet requirements. Composition is intellectual property of BioMar AS

n Inert marker for the evaluation of nutrient digestibility

${ }^{\circ}$ Complete chemical analysis was conducted only for the basal diets (HFM, LFM, HPS). Cholesterol content was analyzed in all diets, bile salt content was analyzed

in five diets as shown in table 
divided into two equal portions labelled as PI1 and PI2 where PI1 constituted the most proximal located portion. A similar separation was performed for the contents of the distal intestines and labelled as DI1 and DI2. Intestinal contents were frozen in liquid nitrogen and stored at $-80{ }^{\circ} \mathrm{C}$ until analysis. For analysis of leucine amino peptidase enzymatic activity, the entire pyloric caeca and distal intestine tissues were immediately frozen in liquid nitrogen in pre-weighed tubes and stored at $-80{ }^{\circ} \mathrm{C}$ before further processing. From five additional fish per tank, distal intestine tissues were fixed in $10 \%$ neutral buffered formalin (4 \% formaldehyde) for $24 \mathrm{~h}$ and subsequently transferred to $70 \% \mathrm{EtOH}$ for storage until processing for histological examination. The remaining fish in each tank were stripped for faeces and continued on feeds for an additional week at which time they were stripped again. Faecal samples were pooled and frozen until analysis.

\section{Chemical analyses}

Diet and faecal samples were analyzed for dry matter (after heating at $105^{\circ} \mathrm{C}$ for $16-18 \mathrm{~h}$ ), ash (combusted at $550{ }^{\circ} \mathrm{C}$ to constant weight), nitrogen (crude protein) (by the semi-micro-Kjeldahl method, Kjeltec-Auto System, Tecator, Höganäs, Sweden), fat (diethylether extraction in a Fosstec analyzer (Tecator) after $\mathrm{HCl}$-hydrolysis), starch (measured as glucose after hydrolysis by alpha-amylase (Novo Nordisk A/S, Bagsvaerd, Denmark) and amyloglucosidase (Bohringer Mannheim $\mathrm{GmbH}$, Mannheim, Germany), followed by glucose determination by the 'Glut-DH method' (Merck, Darmstadt, Germany)), gross energy (using the Parr 1271 Bomb calorimeter, Parr, Moline, IL, USA), and yttrium (by inductivity coupled plasma (ICP) mass-spectroscopy as described by Refstie et al. [21]).

\section{Plasma variables and bile salt levels}

All diets were analyzed for cholesterol by isotope dilution mass spectrometry as described by Schaffer et al. [22]. Plasma was analyzed for cholesterol following standard procedures at the Central Laboratory of the Norwegian University of Life Sciences, Faculty of Veterinary Medicine and Biosciences, Oslo. Total intestinal bile salt levels were measured in plasma and pooled freeze dried gastrointestinal contents from PI1, PI2, MI, DI1, and DI2. Bile salt concentration was determined using the enzyme cycling amplification/Thio - NAD method (Inverness Medical, Cheshire, UK) in the ADVIA ${ }^{\circ} 1650$ Chemistry System (Siemens Healthcare Diagnostics Inc.) at the Central Laboratory. In diet samples and bile taken directly from the gall bladder, glycine and taurine conjugated bile acids were analyzed by HPLC-MS-MS by a modification of the method described by Tagliacocci et al. [23] using deuterium labeled glycine derivatives of bile acids as internal standards. Total bile acids in plasma and in intestinal contents were also analyzed by isotope dilution and combined GC-MS after addition of deuterated cholic acid, chenodeozycholic acid and deoxycholic acid as internal standards followed by deconjugation as described by Björkhem and Falk [24]. The two methods have been shown to give almost identical results. Plasma oxysterols were analyzed by isotope dilution and combined GC-MS after hydrolysis as described by Dzeletovic et al. [25]. Sitosterol and campesterol were assayed by isotope dilution and combined GC-MS after hydrolysis as described by Acimovic et al. [26]. Lathosterol was analyzed by isotope dilution mass spectrometry as described by Lund et al. [27]. $7 \alpha$-hydroxy-4-cholesten-3one (C4) was analyzed by isotope dilution and use of combined HPLC-MS as described by Lövgren-Sandblom et al. [28]. Lipoprotein profiles in plasma were conducted employing size exclusion chromatography and measurements of cholesterol on-line using microliter sample volumes as described by Parini et al. [29].

\section{Histology}

Formalin fixed DI tissue samples were processed using standard histological techniques and stained with haematoxylin and eosin (H\&E). Examination was conducted blinded and in randomized order. The degree of histomorphological change (i.e., deviation from normal) was assessed and assigned to one of four categories: normal, slight, moderate or marked. The following histological characteristics were evaluated: length and fusion of mucosal folds, cellular infiltration and width of the lamina propria and submucosa, enterocyte vacuolization, nucleus position within the enterocytes and the relative number of goblet cells [30, 31].

\section{Calculations}

Crude protein (CP) was calculated as $\mathrm{N} \times$ 6.25. Thermalunit growth coefficient (TGC) was calculated as: TGC $=$ $1000^{*}\left(\mathrm{FBW}^{1 / 3}-\mathrm{IBW}^{1 / 3}\right) \times\left(\Sigma \mathrm{D}^{\circ}\right)^{-1}$, where IBW and FBW are the initial and final body weights (tank means) and $\Sigma \mathrm{D}^{\circ}$ is the thermal sum (feeding days $\times$ average temperature in $\left.{ }^{\circ} \mathrm{C}\right)$. The specific growth rate (SGR) was calculated using the tank means for initial body weight (IBW) and final body weight (FBW) as follows: SGR $=[(\ln \mathrm{FBW}-\ln \mathrm{IBW}) /$ number of days $] \times 100$. Organosomatic indices were calculated as percentages of the weight of the organ in relation to body weight.

\section{Statistical analyses}

Data was analyzed using one-way ANOVA followed by Duncan's test for post hoc comparison. Tank means were used as the statistical unit. Histology data from individual fish were analyzed using Chi-square test. The level of significance was set to $p<0.05$ for all analyses. 


\section{Results}

Diet content of cholesterol and bile salts

As expected, among the diets used in this experiment cholesterol level was higher in the HFM diet than in the LFM and HPS basal diets. Supplementation with cholesterol (suppl mix) increased diet cholesterol concentration (Table 1). Bile salt concentrations were determined in five diets: HFM, LFM, LFM + taurocholate, LFM + suppl mix, and HPS + bovine bile salt diets (Table 1). Unsupplemented diets contained very little bile salts, and as expected the LFM had lower levels than the HFM diet. Supplementation with bile salts, either taurocholate or bovine bile salt, markedly increased dietary bile salt level. The taurocholate supplement was more than $98 \%$ pure, a result that was confirmed by direct analysis (data not shown). The bovine bile salt used as supplement contained a range of bile acids and bile salts. Free bile acids, tauroconjugates and glycoconjucates comprised about 45, 25 and $30 \%$ respectively of this bovine bile preparation.

\section{Fish growth, organ indices and nutrient digestibilities}

Final fish weights, thermal growth coefficients (TGC) and specific growth rates (SGR) are presented in Table 2. TGC and SGR values were significantly lower in fish in the groups fed the LFM and HPS diets compared to those receiving the HFM diet. None of the supplements improved TGC or SGR significantly. The lowest TGC and SGR values were found in the fish fed the bovine bile salt supplemented diets (LFM + bovine bile salt, LFM + suppl mix, HPS + bovine bile salt, and HPS + suppl mix). When supplemented to the LFM diet, the reductions in TGC and SGR values were significant.

Organosomatic indices of the pyloric (PI), mid (MI) and distal (DI) intestines are shown in Table 2. For PI somatic indices significant different treatment effects were observed. The LFM fed fish had significantly higher PI somatic index compared to those fed the HFM and HPS diets. Among the LFM groups of fish, lecithin supplementation led to lower relative PI weights. No differences due to supplementation were observed among the HPS groups. Similar results were observed in the MI, increased weights in the LFM groups compared to HFM and HPS groups, except for the lecithin supplemented groups, which showed similar values as HFM and HPS groups. The opposite situation was observed in the distal intestine. LFM fed fish had similar DI somatic index as those fed HFM, but the HPS groups had a significantly lower DI relative weight. Among the LFM groups, fish fed diets supplemented with bovine bile salt (LFM + bovine bile salt and LFM + suppl mix) had lower DI somatic indices compared to the non-supplemented fish (LFM). The supplementations to the HPS diet did not significantly affect relative weight of DI.

Table 3 shows the results of the digestibility analyses. Only small differences were observed for the protein and lipid digestibilities. Interestingly enough, the LFM diets showed significantly higher protein digestibility than the HFM diet. No significant differences were observed between the LFM and HPS diets. Likewise, no significant differences in lipid digestibility were observed between these diets.

\section{Morphology of the distal intestine}

Slight to moderate inflammatory changes were observed in several samples. See Fig. 1 for numbers of samples from each treatment classified by severity of changes and Fig. 2 for representative histological images. All fish fed the HFM diet appeared normal. Eight out of ten fish fed the LFM diet appeared normal, whereas 2 fish showed slight changes. Supplementing the LFM diet with taurocholate increased the number of samples with slight changes, whereas supplementing the LFM diet with bovine bile salt or the suppl mix clearly increased the number of samples with moderate changes. Other LFM diets did not significantly affect the number of samples with inflammatory changes, or the severity of changes. Varying degrees of accumulation of eosinophilic material within enterocytes (Fig. 3) were frequently observed in fish fed LFM diets. Fish fed the LFM + taurocholate diet had the highest frequency of eosinophilic inclusions, in 8 out of 10 samples.

Table 2 Growth and relative organ weights of Atlantic salmon during the feeding period

\begin{tabular}{|c|c|c|c|c|c|c|c|c|c|c|c|}
\hline & HFM & LFM & $\begin{array}{l}\text { LFM + } \\
\text { Tauro-cholate }\end{array}$ & $\begin{array}{l}\text { LFM + } \\
\text { Bovine bile salt }\end{array}$ & $\begin{array}{l}\text { LFM + } \\
\text { Taurine }\end{array}$ & $\begin{array}{l}\text { LFM + } \\
\text { Lecithin }\end{array}$ & $\begin{array}{l}\text { LFM + } \\
\text { Suppl Mix }\end{array}$ & HPS & $\begin{array}{l}\mathrm{HPS}+ \\
\text { Bovine bile salt }\end{array}$ & $\begin{array}{l}\text { HPS + } \\
\text { Suppl Mix }\end{array}$ & Pooled SEM \\
\hline BW (g) & $789^{a}$ & $709^{b c d}$ & $678^{\mathrm{cd}}$ & $656^{c d}$ & $704^{\text {bcd }}$ & $758^{a b}$ & $638^{d}$ & $681^{\mathrm{cd}}$ & $669^{\text {cd }}$ & $667^{\text {cd }}$ & 17 \\
\hline TGC & $3.04^{\mathrm{a}}$ & $2.54^{\mathrm{bcd}}$ & $2.36^{\text {cde }}$ & $2.09^{e}$ & $2.52^{\mathrm{bcd}}$ & $2.75^{\mathrm{ab}}$ & $2.08^{e}$ & $2.37^{\text {bcde }}$ & $2.24^{\text {cde }}$ & $2.16^{\mathrm{de}}$ & 0.09 \\
\hline$S G R$ & $1.02^{\mathrm{a}}$ & $0.87^{\mathrm{bc}}$ & $0.81^{\mathrm{bcd}}$ & $0.72^{d}$ & $0.86^{b c}$ & $0.92^{\mathrm{ab}}$ & $0.72^{d}$ & $0.81^{\mathrm{bcd}}$ & $0.77^{\mathrm{cd}}$ & $0.74^{d}$ & 0.03 \\
\hline \multicolumn{12}{|c|}{ Organosomatic indicies } \\
\hline PI & $2.02^{c}$ & $2.52^{\mathrm{a}}$ & $2.37^{\mathrm{ab}}$ & $2.30^{\mathrm{abc}}$ & $2.33^{\mathrm{abc}}$ & $2.12^{\mathrm{bc}}$ & $2.41^{\mathrm{ab}}$ & $2.01^{c}$ & $2.09^{b c}$ & $2.09^{b c}$ & 0.08 \\
\hline Ml & $0.17^{\mathrm{ef}}$ & $0.21^{\mathrm{ab}}$ & $0.22^{\mathrm{a}}$ & $0.21^{\mathrm{abc}}$ & $0.19^{c d}$ & $0.17^{f}$ & $0.19^{c d}$ & $0.17^{\mathrm{ef}}$ & $0.19^{\text {de }}$ & $0.19^{\text {def }}$ & 0.005 \\
\hline DI & $0.48^{\mathrm{ab}}$ & $0.49^{\mathrm{a}}$ & $0.47^{\mathrm{abcd}}$ & $0.43^{\text {de }}$ & $0.48^{a b c}$ & $0.49^{\mathrm{ab}}$ & $0.44^{\text {bcde }}$ & $0.39^{e}$ & $0.43^{\text {cde }}$ & $0.40^{\mathrm{e}}$ & 0.01 \\
\hline
\end{tabular}

Abbreviations: $B W$ body weight, TGC thermal growth coefficient, SGR specific growth rate, $P I$ pyloric intestine, $M I$ mid intestine, $D I$ distal intestine. Different letters denote diet groups that are significantly different 
Table 3 Apparent digestibility of crude protein and lipid

\begin{tabular}{llllllllllll}
\hline & HFM & LFM & LFM + & LFM + & LFM + & LFM + & LFM + & HPS & HPS + & HPS + \\
& & & Tauro-cholate & Bovine bile salt & Taurine & Lecithin & Suppl Mix & & Bovine bile salt & Suppl Mix & Pooled SEM \\
\hline Protein & $88.3^{\mathrm{c}}$ & $90.0^{\mathrm{ab}}$ & $89.4^{\mathrm{abc}}$ & $89.0^{\mathrm{bc}}$ & $90.1^{\mathrm{ab}}$ & $90.7^{\mathrm{a}}$ & $89.5^{\mathrm{abc}}$ & $90.2^{\mathrm{a}}$ & $90.0^{\mathrm{ab}}$ & $89.3^{\mathrm{bc}}$ & 0.25 \\
Lipid & $96.5^{\mathrm{a}}$ & $95.7^{\mathrm{abc}}$ & $95.0^{\mathrm{bc}}$ & $95.7^{\mathrm{abc}}$ & $95.2^{\mathrm{abc}}$ & $96.2^{\mathrm{ab}}$ & $94.5^{c}$ & $95.1^{\mathrm{bc}}$ & $96.2^{\mathrm{ab}}$ & $94.6^{c}$ & 0.25 \\
\hline
\end{tabular}

Different letters denote diet groups that are significantly different

Inflammatory responses varied between fish fed HPScontaining diets. When present, changes were typical of soy enteropathy, including decreased enterocyte vacuolization, apical displacement of enterocyte nuclei, leukocyte infiltration of the epithelia and submucosa, and hyperplastic connective tissue in the lamina propria and submucosa. Supplementation of the HPS diet with either the bovine bile salt or the suppl mix did not significantly affect the number of fish showing inflammatory changes, or the severity of changes.

\section{Blood plasma biochemistry}

Blood plasma variables are presented in Table 4. Total plasma cholesterol levels were higher in fish fed cholesterol supplemented diets (suppl mix). No significant differences were observed between fish fed the other diets. Most of the plasma cholesterol was present in the HDL lipoprotein fraction, except in the fishes fed with the cholesterol supplemented diets (suppl mix). In these, most of the cholesterol was present in the LDL fraction and much less in the HDL fraction.

Plasma bile salt concentrations differed between treatments. The individual variation of plasma bile salt was, however, greater than expected, in particular for the groups fed bovine bile salt. The variation was largely reflective of dietary supplementation with bile acids. Although the One-Way ANOVA did not show significant differences

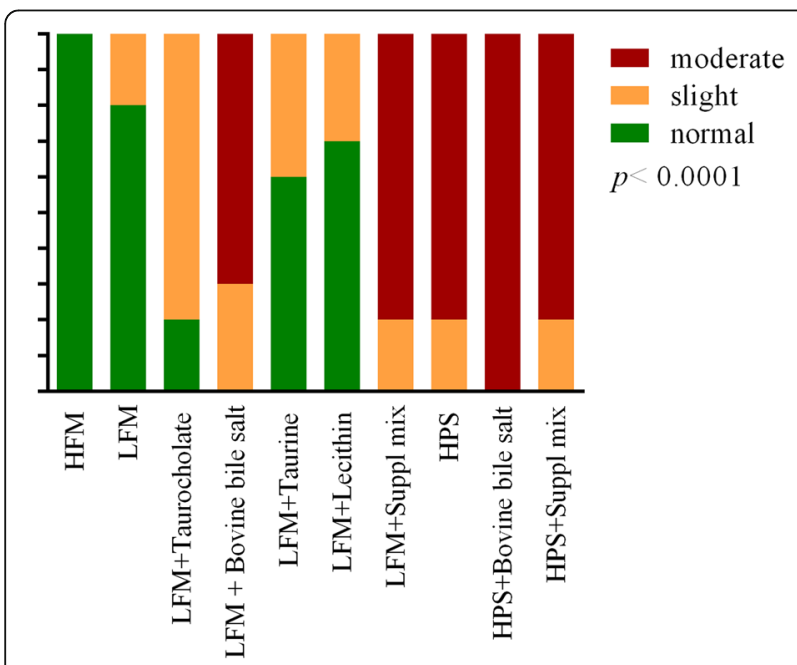

Fig. 1 Number of samples in each diet group classified by severity of inflammatory changes in the distal intestine. The $P$ value for the Chi-square test is given between fish fed any of the basal diets, taking the results of all the LFM treatments without bile salt supplementation together it is clear that fish fed LFM diet had lower plasma total bile salt levels than fish fed the HFM diet. The HPS groups had the lowest plasma bile salt concentration. In fish fed both LFM and HPS, the bovine bile salt and suppl mix groups had higher levels of plasma bile acids compared to groups fed their respective basal diets.

Lathosterol is an intermediate in cholesterol synthesis and the circulating level of this steroid reflects cholesterol synthesis in the liver. As expected, the cholesterolcontaining diets (suppl mix) depressed circulating lathosterol. Lower lathosterol levels were also observed in the LFM groups as compared to HFM and HPS groups. The cholesterol supplemented diets caused markedly increased plasma levels of $7 \alpha$-Hydroxy-4-cholesten-3-one (C4), indicative of conversion of excess cholesterol to bile acids. No significant differences in C4 levels were observed between fish fed the other diets. Marked reduction in plasma levels of the plant sterols sitosterol and campesterol were observed for fish fed the cholesterol-containing diets (suppl mix). Supplementation with taurocholate, taurine and the bovine bile salt also reduced plasma plant sterol levels, but

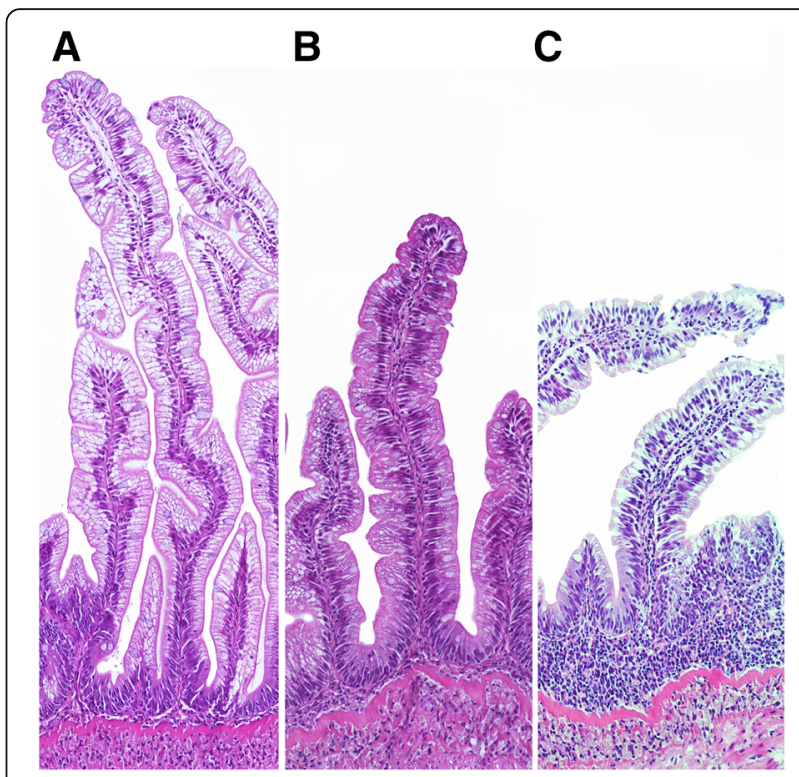

Fig. 2 Distal intestinal histolomorphology showing representative appearance of sections that were graded as (a) normal, (b) mild, or (c) moderate changes characteristic of soybean meal-induced distal intestinal enteritis 


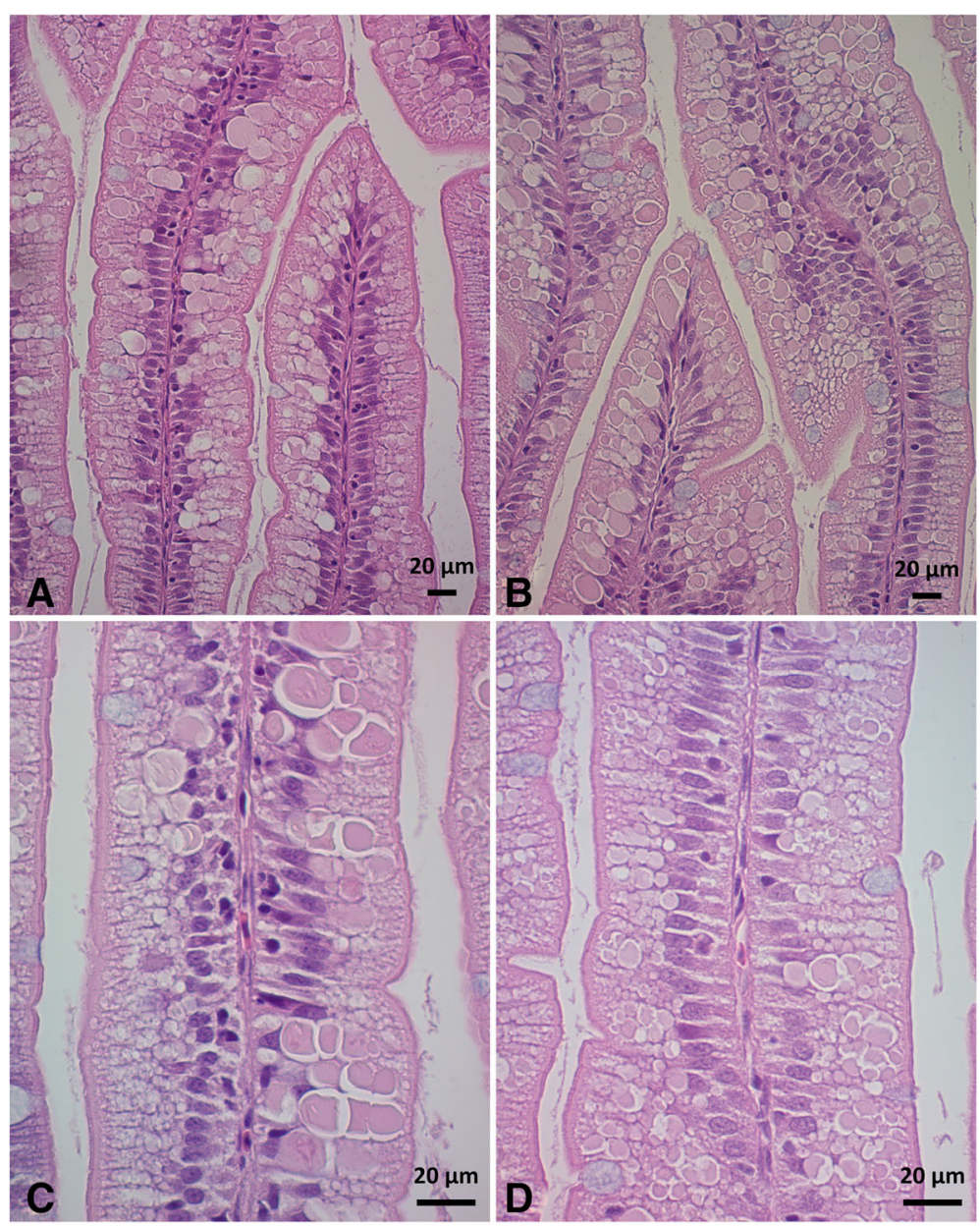

Fig. 3 Eosinophilic inclusions within distal intestine enterocytes in (a) LFM, (b) LFM + taurocholate, (c) LFM, and (d) LFM + taurocholate fed fish

to a lesser extent. Plasma levels of oxysterols were markedly higher in the two cholesterol supplemented groups, whereas few differences were observed between fish fed the other diets.

\section{Gall bladder bile}

Bile taken directly from the gall bladder was analyzed for individual bile salts. Total, conjugated and unconjugated bile salt concentrations are shown in Table 5. No significant differences in total concentrations were found between the LFM and HPS fed groups of fish compared to the HFM fed fish. Bovine bile salt supplementation increased or tended to increase total bile acid concentrations when added to both the LFM and HPS diets. The majority of bile acids in the gallbladder bile were conjugated; the only unconjugated bile acid found was cholic acid which was detected at low concentration. The taurine conjugated bile acids were the predominant form of bile acids found in the bile, with taurocholic acid being the predominant individual bile acid. Taurodeoxycholic acid was higher in the bile of fish groups fed diets supplemented with the bovine bile salt. The glycine conjugated bile acids were detected at very low concentrations except for the groups fed diets supplemented with bovine bile salt. The glycine conjugated bile acids were also largely responsible for differences observed in total bile acid concentrations since no statistically significant differences were observed in total taurine conjugated bile acids.

\section{Brush border membrane leucine aminopeptidase activity}

Leucine aminopeptidase activities were analyzed in pyloric and distal intestine tissue and expressed as total activity per $\mathrm{kg}$ fish weight. In the PI, no significant effects of basal diet formulation or any of the supplementations were found (data not shown). In the DI, the HPS groups showed lower enzyme activity compared to the HFM and LFM groups (Fig. 4). Groups fed diets with the suppl mix, i.e., both the LFM and HPS groups, showed the lowest activities. Fish fed the diets with bovine bile salt also showed lower enzyme activity compared to the LFM control. Supplementation with either bovine bile salt or suppl mix to the HPS formulation did not result in 
Table 4 Mean values ( $n=$ ten fish pr diet group) for blood plasma variables

\begin{tabular}{|c|c|c|c|c|c|c|c|c|c|c|c|}
\hline & HFM & LFM & $\begin{array}{l}\text { LFM+ Tauro } \\
\text { cholate }\end{array}$ & $\begin{array}{l}\text { LFM+ Bovine } \\
\text { bile salt }\end{array}$ & $\begin{array}{l}\text { LFM+ } \\
\text { Taurine }\end{array}$ & $\begin{array}{l}\text { LFM+ } \\
\text { Lecithin }\end{array}$ & $\begin{array}{l}\text { LFM+ Suppl } \\
\text { mix }\end{array}$ & HPS & $\begin{array}{l}\text { HPS+ Bovine } \\
\text { bile salt }\end{array}$ & $\begin{array}{l}\text { HPS+ Suppl } \\
\text { mix }\end{array}$ & $\begin{array}{l}\text { pooled } \\
\text { SEM }\end{array}$ \\
\hline Total CH (mmol/l) & $10.7^{a}$ & $8.3^{\mathrm{a}}$ & $8.5^{a}$ & $8.4^{\mathrm{a}}$ & $8.4^{\mathrm{a}}$ & $9.5^{a}$ & $24.6^{\mathrm{b}}$ & $8.6^{a}$ & $8.9^{\mathrm{a}}$ & $24.6^{\mathrm{b}}$ & 1.1 \\
\hline VLDL-CH ${ }^{\mathrm{a}}$ & 0.1 & 0.1 & 0.2 & 0.2 & 0.2 & 0.1 & 0.5 & 0.2 & 0.1 & 0.5 & \\
\hline $\mathrm{LDL}-\mathrm{CH}^{\mathrm{a}}$ & 1.6 & 1.3 & 0.9 & 1.0 & 0.9 & 0.9 & 19.9 & 0.9 & 1.0 & 23.5 & \\
\hline $\mathrm{HDL}-\mathrm{CH}^{\mathrm{a}}$ & 10.5 & 7.5 & 6.6 & 7.9 & 6.4 & 8.0 & 7.3 & 7.5 & 5.8 & 9.1 & \\
\hline Bile salts ( $\mu \mathrm{mol} / \mathrm{l})$ & $31^{\mathrm{abc}}$ & $20^{b c}$ & $23^{a b c}$ & $48^{\mathrm{ab}}$ & $22^{\mathrm{bc}}$ & $15^{\mathrm{bc}}$ & $55^{\mathrm{a}}$ & $6^{c}$ & $41^{\mathrm{ab}}$ & $23^{\mathrm{abc}}$ & 7 \\
\hline Lathosterol ( $\mu \mathrm{g} / \mathrm{ml})$ & $6.6^{\mathrm{b}}$ & $3.8^{\mathrm{cd}}$ & $3.2^{\text {de }}$ & $3.5^{\mathrm{d}}$ & $4.7^{c}$ & $4.6^{c}$ & $2.4^{\mathrm{ef}}$ & $5.8^{\mathrm{b}}$ & $3.6^{d}$ & $2.5^{\mathrm{ef}}$ & 0.4 \\
\hline C4 (ng/ml) & $13^{\mathrm{a}}$ & $10^{\mathrm{a}}$ & $10^{\mathrm{a}}$ & $10^{\mathrm{a}}$ & $13^{\mathrm{a}}$ & $11^{\mathrm{a}}$ & $200^{b}$ & $12^{\mathrm{a}}$ & $9^{a}$ & $180^{\mathrm{b}}$ & 8 \\
\hline Sitosterol( $\mu \mathrm{g} / \mathrm{ml})$ & $67^{\mathrm{ab}}$ & $74^{a}$ & $47^{c d}$ & $52^{b c d}$ & $44^{d}$ & $64^{\mathrm{ab}}$ & $6^{e}$ & $64^{\mathrm{ab}}$ & $40^{d}$ & $6^{e}$ & 4 \\
\hline Campesterol( $\mu \mathrm{g} / \mathrm{ml})$ & $229^{a}$ & $188^{\mathrm{ab}}$ & $151^{\mathrm{b}}$ & $160^{\mathrm{b}}$ & $133^{b}$ & $220^{\mathrm{a}}$ & $14^{c}$ & $239^{a}$ & $162^{b}$ & $18^{c}$ & 16 \\
\hline \multicolumn{12}{|l|}{ Oxysterols $(\mathrm{ng} / \mathrm{m} /)^{\mathrm{a}}$} \\
\hline 7a-hydroxy-CH & 124 & 130 & 111 & 116 & 172 & 116 & 1800 & 103 & 591 & 2110 & \\
\hline $7 \beta$-hydroxy-CH & 52 & 37 & 40 & 42 & 66 & 29 & 238 & 32 & 404 & 285 & \\
\hline 7-keto-hydroxy-CH & 130 & 101 & 122 & 125 & 201 & 59 & 730 & 89 & 1915 & 554 & \\
\hline 24-hydroxy-CH & 3.6 & 2.2 & 1.8 & 2.0 & 3.3 & 3.5 & 7.1 & 3.8 & 5.3 & 11.5 & \\
\hline 25-hydroxy-CH & 5 & 5 & 7 & 8 & 9 & 7 & 36 & 5 & 15 & 40 & \\
\hline 27-hydroxy-CH & 34 & 21 & 14 & 17 & 42 & 22 & 64 & 32 & 22 & 92 & \\
\hline
\end{tabular}

a Lipoprotein and oxysterol profiles were measured in a pooled sample of $n=$ ten animals pr diet group. CV for the different assays, i.e., the analytical variance, as estimated by analyzing a control sample over 10 consecutive days: VLDL-CH: $8.1 \%$, LDL-CH: $3.4 \%$, HDL-CH: $5.0 \%$, VLDL-TAG: $13.1 \%$, LDL-TAG: $10.5 \%$, HDL-TAG: $9.7 \%$. CVs for all oxysterol assays are $<8 \%$, except for 25 -hydroxy-CH $(11 \%){ }^{(25)}$. Different letters denote diet groups that are significantly different

significant effects regarding this enzyme activity compared to the respective unsupplemented diets.

\section{Dry matter, trypsin activity and bile salt levels in} intestinal content

Dry matter (DM) of digesta in the intestinal sections (PI1, PI2, MI, DI1, DI2) are presented in Table 6. No statistically significant differences were found in DM of digesta from the PI and MI. However, the trends observed in these regions became significant in the DI. The digesta DM of fish fed the LFM diet did not differ significantly from those fed the HFM diet, but the HPS groups showed significantly lower digesta DM in both the DI segments. For the LFM fed groups, bile salt supplementation tended to decrease DM. No differences due to any of the supplementation were observed among the HPS diets. Trypsin activities in intestinal regions are shown in Table 6. In the distal half of the DI, trypsin activities in fish fed the LFM diet were low and similar to fish fed the HFM diet. Fish fed the HPS diet showed significantly higher trypsin activity as compared to the other controls. Fish fed bile salt (taurocholate, bovine

Table 5 Mean values ( $n=$ ten fish pr diet group) for gall bladder bile acid levels

\begin{tabular}{|c|c|c|c|c|c|c|c|c|c|c|c|}
\hline & HFM & LFM & $\begin{array}{l}\text { LFM+ Tauro } \\
\text { cholate }\end{array}$ & $\begin{array}{l}\text { LFM+ Bovine } \\
\text { bile salt }\end{array}$ & $\begin{array}{l}\text { LFM+ } \\
\text { Taurine }\end{array}$ & $\begin{array}{l}\text { LFM+ } \\
\text { Lecithin }\end{array}$ & $\begin{array}{l}\text { LFM+ Suppl } \\
\text { mix }\end{array}$ & HPS & $\begin{array}{l}\text { HPS+ Bovine } \\
\text { bile salt }\end{array}$ & $\begin{array}{l}\text { HPS+ Suppl } \\
\text { mix }\end{array}$ & $\begin{array}{l}\text { pooled } \\
\text { SEM }\end{array}$ \\
\hline Total bile acids & $99^{c d}$ & $117^{\mathrm{bcd}}$ & $112^{\mathrm{bcd}}$ & $137^{\mathrm{ab}}$ & $104^{b c d}$ & $95^{d}$ & $139^{\mathrm{ab}}$ & $112^{\mathrm{bcd}}$ & $161^{\mathrm{a}}$ & $134^{\mathrm{abc}}$ & 9 \\
\hline Total conjugated & $99^{c d}$ & $117^{\mathrm{bcd}}$ & $112^{\mathrm{bcd}}$ & $136^{a b}$ & $104^{\mathrm{bcd}}$ & $95^{d}$ & $138^{a b}$ & $112^{\mathrm{bcd}}$ & $161^{\mathrm{a}}$ & $133^{\mathrm{abc}}$ & 9 \\
\hline Total unconjugated & $<0.1^{c}$ & $<0.1^{c}$ & $<0.1^{c}$ & $0.6^{\mathrm{b}}$ & $<0.1^{c}$ & $<0.1^{\mathrm{c}}$ & $1.2^{\mathrm{a}}$ & $<0.1^{c}$ & $0.3^{b c}$ & $1.0^{\mathrm{a}}$ & $<0.1$ \\
\hline Taurine conjugated & $99^{\mathrm{cd}}$ & $117^{\mathrm{bcd}}$ & $112^{\mathrm{bcd}}$ & $97^{c d}$ & $104^{\mathrm{bcd}}$ & $95^{d}$ & $113^{\mathrm{bcd}}$ & $112^{\mathrm{bcd}}$ & $122^{\mathrm{b}}$ & $107^{\mathrm{bcd}}$ & 8 \\
\hline$T-C A$ & $92^{\mathrm{ab}}$ & $110^{\mathrm{a}}$ & $108^{\mathrm{a}}$ & $66^{\mathrm{b}}$ & $99^{\mathrm{ab}}$ & $89^{\mathrm{ab}}$ & $92^{\mathrm{ab}}$ & $100^{\mathrm{ab}}$ & $87^{\mathrm{ab}}$ & $83^{\mathrm{ab}}$ & 9 \\
\hline$T-C D C A$ & $7^{\mathrm{bc}}$ & $6^{c}$ & $2^{d}$ & $6^{c}$ & $5^{c d}$ & $6^{c}$ & $9^{b c}$ & $13^{\mathrm{a}}$ & $7^{\mathrm{bc}}$ & $10^{\mathrm{ac}}$ & 1 \\
\hline$T-D C A$ & $<0.1^{\mathrm{C}}$ & $<0.1^{c}$ & $2^{c}$ & $25^{\mathrm{a}}$ & $<0.1^{c}$ & $<0.1^{c}$ & $12^{\mathrm{b}}$ & $<0.1^{c}$ & $28^{\mathrm{a}}$ & $14^{\mathrm{b}}$ & 1 \\
\hline Glycine conjugated & $<0.1^{c}$ & $<0.1^{c}$ & $<0.1^{c}$ & $39^{a}$ & $<0.1^{c}$ & $<0.1^{c}$ & $25^{\mathrm{b}}$ & $0.1^{c}$ & $39^{\mathrm{a}}$ & $26^{b}$ & 1 \\
\hline G-CA & $<0.1^{c}$ & $<0.1^{c}$ & $<0.1^{c}$ & $27^{a}$ & $<0.1^{c}$ & $<0.1^{c}$ & $19^{b}$ & $0.1^{c}$ & $30^{a}$ & $19^{\mathrm{b}}$ & 1 \\
\hline$G-C D C A$ & $<0.1^{d}$ & $<0.1^{d}$ & $<0.1^{d}$ & $1.9^{a}$ & $<0.1^{d}$ & $<0.1^{d}$ & $0.8^{c}$ & $<0.1^{d}$ & $1.4^{\mathrm{b}}$ & $0.9^{c}$ & $<0.1$ \\
\hline$G-D C A$ & $<0.1^{d}$ & $<0.1^{d}$ & $<0.1^{d}$ & $9.8^{\mathrm{a}}$ & $<0.1^{d}$ & $<0.1^{d}$ & $5.3^{c}$ & $<0.1^{d}$ & $8.1^{\mathrm{ab}}$ & $6.1^{b c}$ & 0.3 \\
\hline
\end{tabular}

Abbreviations: $T$ - tauro-, G- glyco, CA colic acid, CDCA chenodeoxycholic acid, DCA deoxycholic acid. Different letters denote diet groups that are significantly different 


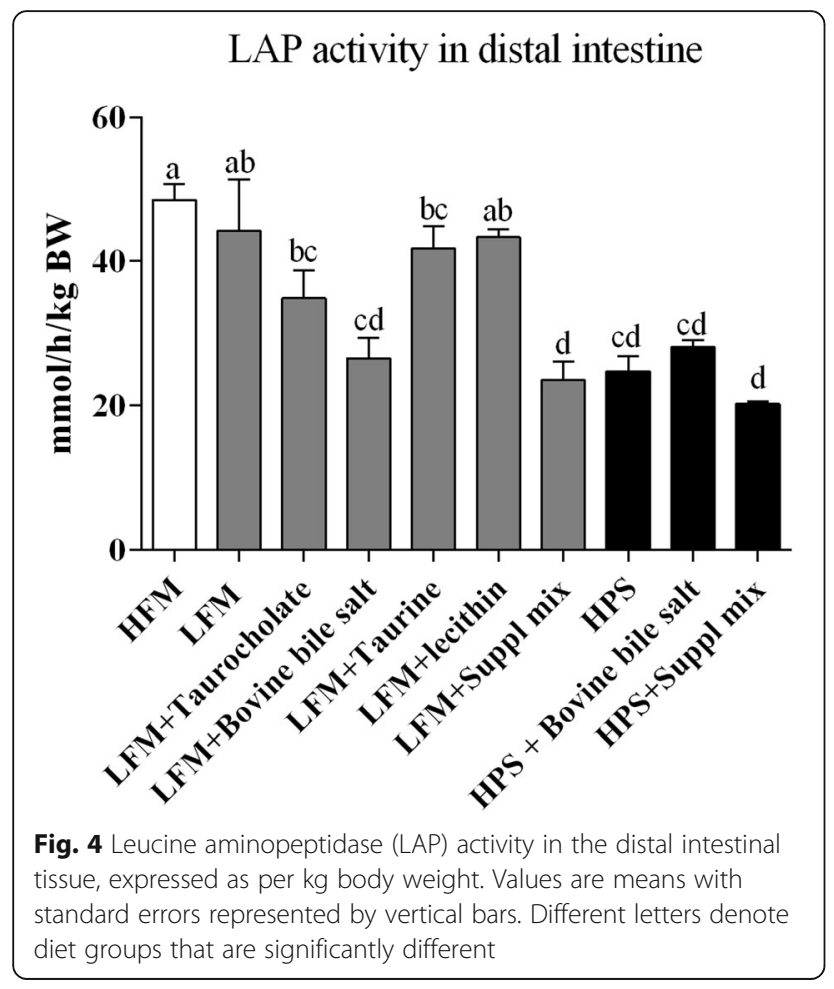

bile salt and suppl mix) supplemented LFM diets had higher trypsin activity compared to their respective control and similar to the HPS groups. Levels were high in all HPS groups, and no effect of supplementation was observed. No statistically significant differences in digesta bile salt concentrations were observed for any of the treatments, in any of the intestinal regions (Table 6).

\section{Discussion}

Effects of basal diet

In the present study, the two plant based diets (LFM and HPS) suppressed fish growth performance as compared to the high fish meal control diet (HFM). Animal growth parameters are arguably among the most appropriate and practical response variables for examining the effects of variation in diet composition, and a large body of literature has described effects of inclusion of fish meal alternatives on fish growth performance (reviewed by $[32,33])$. The lower growth rates observed for the LFM and HPS diets were probably related to, or directly caused by the observed histomorphological changes in the distal intestine and the accompanying signs of gut dysfunction. Slight to moderate signs of enteritis in the distal intestine were observed in 2 and 10 out of 10 fish in the LFM and HPS fed fish, respectively. The changes were typical of soybean meal induced enteritis (SBMIE), including decreased enterocyte vacuolization, apical displacement of enterocyte nuclei,

Table 6 Dry matter (DM) content, trypsin activity and bile salt levels in digesta of Atlantic salmon

\begin{tabular}{|c|c|c|c|c|c|c|c|c|c|c|c|}
\hline & HFM & LFM & $\begin{array}{l}\text { LFM + } \\
\text { Tauro-cholate }\end{array}$ & $\begin{array}{l}\text { LFM + } \\
\text { Bovine bile salt }\end{array}$ & $\begin{array}{l}\text { LFM + } \\
\text { Taurine }\end{array}$ & $\begin{array}{l}\text { LFM + } \\
\text { Lecithin }\end{array}$ & $\begin{array}{l}\text { LFM + } \\
\text { Suppl Mix }\end{array}$ & HPS & $\begin{array}{l}\text { HPS + } \\
\text { Bovine bile salt }\end{array}$ & $\begin{array}{l}\text { HPS + } \\
\text { Suppl Mix }\end{array}$ & Pooled SEM \\
\hline \multicolumn{12}{|c|}{ Digesta dry matter (mg/g) } \\
\hline PI1 & 10.1 & 9.3 & 8.4 & 8.2 & 9.0 & 10.7 & 9.9 & 9.1 & 9.2 & 10.4 & 0.54 \\
\hline $\mathrm{PI} 2$ & 11.9 & 11.0 & 10.3 & 9.6 & 11.5 & 12.1 & 11.5 & 12.3 & 10.5 & 12.1 & 0.58 \\
\hline $\mathrm{Ml}$ & 14.1 & 12.9 & 12.2 & 11.2 & 12.6 & 13.8 & 13.1 & 13.2 & 12.8 & 14.0 & 0.54 \\
\hline Dl1 & $14.0^{\mathrm{a}}$ & $12.9^{\mathrm{ab}}$ & $11.4^{\mathrm{bcd}}$ & $11.2^{\mathrm{cd}}$ & $12.3^{\mathrm{bcd}}$ & $13.1^{\mathrm{ab}}$ & $11.8^{\mathrm{bcd}}$ & $10.9^{c}$ & $12.8^{\mathrm{abc}}$ & $11.6^{\mathrm{bcd}}$ & 0.38 \\
\hline $\mathrm{D} 12$ & $11.8^{\mathrm{ab}}$ & $11.0^{\mathrm{bc}}$ & $9.3^{\text {de }}$ & $9.7^{\text {cde }}$ & $10.7^{\mathrm{bcd}}$ & $12.1^{\mathrm{ab}}$ & $10.0^{\mathrm{cd}}$ & $8.3^{e}$ & $9.4^{\text {cde }}$ & $8.1^{\mathrm{e}}$ & 0.32 \\
\hline \multicolumn{12}{|c|}{ Digesta trypsin activity (U/mg DM) } \\
\hline PI1 & $308^{\mathrm{abc}}$ & $232^{b c}$ & $221^{c}$ & $293^{\mathrm{abc}}$ & $234^{\mathrm{bc}}$ & $226^{c}$ & $234^{\mathrm{bc}}$ & $335^{\mathrm{a}}$ & $330^{\mathrm{ab}}$ & $344^{a}$ & 29 \\
\hline $\mathrm{Pl} 2$ & $182^{\mathrm{ab}}$ & $113^{b c}$ & $132^{b c}$ & $175^{\mathrm{abc}}$ & $108^{\mathrm{bc}}$ & $93^{c}$ & $158^{\mathrm{bc}}$ & $155^{\mathrm{bc}}$ & $192^{\mathrm{ab}}$ & $249^{a}$ & 24 \\
\hline $\mathrm{Ml}$ & 106 & 72 & 72 & 139 & 78 & 53 & 87 & 78 & 126 & 120 & 30 \\
\hline Dl1 & $50^{\mathrm{abc}}$ & $38^{c}$ & $47^{\mathrm{abc}}$ & $79^{a}$ & $41^{\mathrm{bc}}$ & $37^{c}$ & $67^{\mathrm{abc}}$ & $56^{\mathrm{abc}}$ & $74^{\mathrm{ab}}$ & $64^{\mathrm{abc}}$ & 10 \\
\hline $\mathrm{D} 12$ & $7^{c}$ & $8^{c}$ & $25^{b}$ & $48^{\mathrm{a}}$ & $6^{c}$ & $10^{c}$ & $37^{\mathrm{ab}}$ & $35^{\mathrm{ab}}$ & $37^{\mathrm{ab}}$ & $41^{\mathrm{a}}$ & 5 \\
\hline \multicolumn{12}{|c|}{ Digesta bile salt levels (mg/g DM) } \\
\hline Pl1 & 290 & 355 & 376 & 367 & 356 & 285 & 268 & 330 & 346 & 299 & 75 \\
\hline $\mathrm{PI} 2$ & 228 & 262 & 256 & 303 & 268 & 292 & 290 & 242 & 301 & 251 & 57 \\
\hline $\mathrm{Ml}$ & 171 & 218 & 205 & 207 & 275 & 220 & 275 & 159 & 183 & 204 & 44 \\
\hline Dl1 & 78 & 74 & 98 & 103 & 124 & 63 & 83 & 97 & 99 & 92 & 34 \\
\hline $\mathrm{D} 12$ & 5 & 10 & 11 & 11 & 16 & 5 & 15 & 15 & 14 & 17 & 7 \\
\hline
\end{tabular}

Different letters denote diet groups that are significantly different 
leukocyte infiltration of the epithelia and submucosa, and hyperplastic connective tissue in the lamina propria and submucosa [30, 31]. The histomorphological changes in the soya (HPS) fed fish were milder than what is typically observed in feeding trials with Atlantic salmon fed full-fat or extracted soya. The reason for this is not clear, but a likely explanation could be that the soy variant used in the current study contained lower levels of antinutrients, such as saponins.

The observed histomorphological alterations in fish fed the LFM and HPS diets were accompanied by alterations in a panel of indicators of gut function, most pronounced for the HPS groups. Decreased faecal dry matter, first reported in salmon by van den Ingh and coworkers [30], is frequently observed during distal intestinal inflammations and is probably a result of impaired ability to absorb water in the inflamed and damaged intestine. Decreased weight of the DI, as seen for fish fed the HPS diet, is also typically observed in concert with intestinal inflammation, apparently due to loss of intestinal mucosa [34]. Brush border membrane enzyme activity is a sensitive indicator of enterocyte dysfunction and changes may be present even in the absence of altered tissue histology. The lower LAP activity in fish fed HPS diets is in agreement with presence of SBMIE [3]. The higher trypsin activity, as seen for fish fed the HPS diet, is also commonly observed during intestinal inflammatory conditions. Trypsin activity in DI digesta typically shows a correlation with the severity of morphological changes associated with SBMIE [3, 35, 36]. Furthermore, the two plant diets tended to reduce blood plasma cholesterol and bile acid levels. This is a commonly observed response to plant feed ingredients, with their content of fibers, phytosterols, phytoestrogens and saponins that all may affect cholesterol and bile salt absorption from the intestine [37]. Increased levels of plant ingredients in formulated feeds will also reduce the dietary load of cholesterol and bile acids, as demonstrated in the present study. Dietary supplementation of plant based fish feeds with cholesterol and/or bile components have therefore been subject to systematic investigations, in order to assess if removal of marine based feed ingredients may create a deficiency of any of these compounds. These results are discussed in the following section.

\section{Effects of supplements}

The main finding of the present work was that supplementation with bile salts, either as pure taurocholate or as a mix of bovine bile salts did not reduce signs of enteritis in the distal intestine. Similarly, supplementation with lecithin, taurine or combinations of bile acids, cholesterol and lecithin were also ineffective in ameliorating enteritic changes. The results of the present investigation contrast previous reports in rainbow trout $[5,18,19]$, where supplementation with bovine bile salts (1.5-2.0\%), taurocholate $(1.0 \%)$ or soybean lecithin $(2.0 \%)$ were reported to prevent SBM-induced morphological abnormalities in the DI. Bile salt supplementation was also interpreted to restore growth, feed efficiency and intestinal maltase activity to comparable levels reported in the control group [5]. In contrast, the present study clearly indicated that supplementation with bovine bile salt at similar levels (1.8 \%), either alone or in the suppl mix, impaired intestinal function. The strongest responses were seen when the bovine bile salt was supplemented to the LFM diet, as witnessed by reduced DI relative weight and LAP activity, increased trypsin activity in DI digesta and clear signs of enteritis in the DI. A likely explanation for the observed negative effects would be cytotoxic actions of the bile salts on intestinal mucosa. Toxicity of bile acids is thought to be highly correlated with its hydrophobicity. Therefore, the high levels (45\%) of unconjugated, more hydrophobic bile acids in the bovine bile salt may be the reason for the observed negative responses. The bovine bile salt also reduced fish growth. Feed intake was not monitored during the trial, and therefore, supplementation effects on palatability cannot be assessed. However, it is possible that the bovine bile salt may have caused reduced palatability.

There are likely direct interactions between bile acids and intestinal immunity. For example, in mammalian IBD models, activation of the nuclear receptor farnesoid $\mathrm{X}$ receptor (FXR) by natural or synthetic ligands has been associated with immunosuppressive actions and preservation of intestinal epithelial barrier integrity [38]. Specifically, FXR activation has been shown to decrease epithelial permeability and suppress proinflammatory cytokine levels in murine intestinal mucosa [17]. Additionally, FXR activation is inhibited by proinflammatory stimuli in different model systems [16]. As bile acids are natural endogenous FXR ligands, this may point to a direct role of bile salts in modulation of immune responses via FXR. Whether a similar mechanism exists in fish is currently unknown. However, a recent study demonstrated that FXR mRNA levels are strongly induced in the DI of Atlantic salmon suffering from SBMIE, concurrent with a marked induction of proinflammatory cytokines and alterations in bile salt metabolism $[2,39]$.

Reported studies of dietary inclusion of bile salts to teleost fish feeds are, to our knowledge, limited to the above mentioned studies with rainbow trout and our present work with salmon. In contrast, many studies have investigated dietary supplementation with cholesterol, taurine and lecithin/phospholipids to formulated fish feeds, in order to estimate requirements (reviewed in $[20,40,41])$. Reported results are not consistent, but positive effects of inclusion on fish growth and feed intake have often been observed, most prominent during 
larval and early juvenile stages. For adult fish, reported studies are fewer, but requirements of dietary cholesterol, taurine and lecithin/phospholipids are probably species-specific and absorption along the gut dependent on diet formulation. Importantly, evaluation of gut health and function, for example by histological examination, has not been carried out in most of these studies. Given that future fish feeds most likely will contain lower levels of cholesterol, bile salts and marine phospholipids, more research within this area is clearly warranted.

\section{Conclusions}

In conclusion, dietary supplementation with bile components or lecithin in general did not improve endpoints regarding performance or gut health in Atlantic salmon, in clear contrast to what has been previously reported for rainbow trout. Thus, our work does not add to the understanding of a relationship between intestinal inflammation and deficiencies of bile acids and taurine. The reason why our results differ from previous observations in rainbow trout may be the general bile salt status of the fish and/or species differences. Follow-up studies are needed to clarify if lower levels of bile salts and cholesterol may give different and beneficial effects, and if other supplements and other combinations of supplements might improve the inflammation status of the distal intestine. The present study complements our previous report from the same feeding trial [42] and demonstrates how dietary cholesterol and bile salts are taken up and metabolized in Atlantic salmon, showing clear effects of the dietary supplements on gall bladder bile acid levels, cholesterol lipoprotein profiles and plasma levels of oxysterols and markers for cholesterol synthesis and breakdown.

\section{Acknowledgements}

The present paper publishes results of contract research mainly funded by BioMar AS. The Aquaculture Protein Centre (APC) at the Norwegian School of Veterinary Science, a Centre of Excellence under the Norwegian Research Council (Project no. 145949/120), was the main scientific partner of the work. The authors wish to thank the senior researcher Gerd Marit Berge and technicians at Nofima Research Station at Sunndalsøra, Norway for skillful animal care and scientific follow up, and APC's technicians Ellen K. Hage, Elin C. Valen and Gunn C. Østby for excellent technical assistance.

\section{Funding}

The present paper publishes results of contract research mainly funded by BioMar AS.

The funding body participated in study design, but had no role in data collection, analysis and interpretation, decision to publish, or preparation of the manuscript.

\section{Availability of data and materials}

All data supporting the findings is contained within the manuscript.

\section{Authors' contributions}

The authors' contributions were as follows: TMK: data evaluation and interpretation, manuscript development, MHP: experimental design, data evaluation and interpretation, IB: data evaluation and interpretation, KM: experimental design, data evaluation and interpretation, ÅK: leadership, experimental design, data evaluation and interpretation, manuscript development. All authors read and approved the final manuscript.

\section{Competing interests}

The present paper publishes results of contract research mainly funded by BioMar AS. Co-author Kjell Måsøval is employed by BioMar AS.

\section{Consent for publication}

Not applicable.

\section{Ethics approval and consent to participate}

Rearing of the fish were conducted at Nofima's Research Station (Sunndalsøra, Norway), which is an approved research facility by Norwegian Animal Research Authority (NARA) and operates in accordance with the Norwegian Regulations of 17 June 2008 No. 822: Regulations relating to Operation of Aquaculture Establishments (Aquaculture Operation Regulations). Up to sacrifice and sampling, the fish were treated as production fish in accordance with aforementioned Aquaculture Operation Regulations. Prior to sampling, randomly chosen, individual fish were removed from their respective tanks with nets, and humanely anaesthetized and euthanized in water containing a lethal dose of anaesthetic, in accordance with the Norwegian Animal Welfare act. No surgical manipulation of live fish was conducted and tissue samples were only retrieved from euthanized fish. The experimental diets contained ingredients commonly used in commercial feeds and do not cause the fish any apparent distress. Hence, no NARA approval was required according to $\$ 2$ of the Norwegian Regulation on Animal Experimentation.

\section{Author details}

${ }^{1}$ Department of Basic Sciences and Aquatic Medicine, Faculty of Veterinary Medicine and Biosciences, Norwegian University of Life Sciences, Oslo, Norway. ${ }^{2}$ Department of Laboratory Medicine, Division for Clinical Chemistry, Karolinska University Hospital, Huddinge, Sweden. ${ }^{3}$ Biomar AS, Nordre gate 11, 7011 Trondheim, Norway. ${ }^{4}$ Present Address: US Fish \& Wildlife Service, Lamar, PA 16848, USA

Received: 10 November 2015 Accepted: 1 September 2016 Published online: 07 September 2016

\section{References}

1. Kaushik SJ, Cravedi JP, Lalles JP, Sumpter J, Fauconneau B, Laroche M. Partial or total replacement of fish-meal by soybean protein on growth, proteinutilization, potential estrogenic or antigenic effects, cholesterolemia and flesh quality in rainbow-trout, Oncorhynchus mykiss. Aquaculture. 1995;133:257-74.

2. Kortner TM, Gu J, Krogdahl A, Bakke AM. Transcriptional regulation of cholesterol and bile acid metabolism after dietary soybean meal treatment in Atlantic salmon, Salmo salar L. Br J Nutr. 2013;109:593-604.

3. Krogdahl $\AA$, Bakke-McKellep AM, Baeverfjord G. Effects of graded levels of standard soybean meal on intestinal structure, mucosal enzyme activities, and pancreatic response in Atlantic salmon (Salmo salar L.). Aquaculture Nutr. 2003:9:361-71.

4. Sitja-Bobadilla A, Pena-Llopis S, Gomez-Requeni P, Medale F, Kaushik S, Perez-Sanehez J. Effect of fish meal replacement by plant protein sources on non-specific defence mechanisms and oxidative stress in gilthead sea bream (Sparus aurata). Aquaculture. 2005;249:387-400.

5. Yamamoto T, Suzuki N, Furuita H, Sugita T, Tanaka N, Goto T. Supplemental effect of bile salts to soybean meal-based diet on growth and feed utilization of rainbow trout Oncorhynchus mykiss. Fish Sci. 2007;73:123-31.

6. Yun BA, Mai KS, Zhang WB, Xu W. Effects of dietary cholesterol on growth performance, feed intake and cholesterol metabolism in juvenile turbot (Scophthalmus maximus L.) fed high plant protein diets. Aquaculture. 2011;319:105-10.

7. Gu M, Kortner TM, Penn M, Hansen AK, Krogdahl Å. Effects of dietary plant meal and soya-saponin supplementation on intestinal and hepatic lipid droplet accumulation and lipoprotein and sterol metabolism in Atlantic salmon (Salmo salar L.). Br J Nutr. 2014;111:432-44.

8. Romarheim OH, Skrede A, Gao YL, Krogdahl Å, Denstadli V, Lilleeng E, Storebakken T. Comparison of white flakes and toasted soybean meal partly replacing fish meal as protein source in extruded feed for rainbow trout (Oncorhynchus mykiss). Aquaculture. 2006;256:354-64. 
9. Romarheim OH, Skrede A, Penn M, Mydland LT, Krogdahl Å, Storebakken T. Lipid digestibility, bile drainage and development of morphological intestinal changes in rainbow trout (Oncorhynchus mykiss) fed diets containing defatted soybean meal. Aquaculture. 2008;274:329-38.

10. Krogdahl A, Gajardo K, Kortner TM, Penn M, Gu M, Berge GM, Bakke AM. Soya Saponins induce enteritis in Atlantic Salmon (Salmo salar L.). J Agric Food Chem. 2015;63:3887-902.

11. Vinarova L, Vinarov Z, Atanasov V, Pantcheva I, Tcholakova S, Denkov N, Stoyanov S. Lowering of cholesterol bioaccessibility and serum concentrations by saponins: in vitro and in vivo studies. Food Funct. 2015;6:501-12.

12. Lee SO, Simons AL, Murphy PA, Hendrich S. Soyasaponins lowered plasma cholesterol and increased fecal bile acids in female golden Syrian hamsters. Expn Biol Med. 2005;230:472-8.

13. Malinow MR, Mclaughlin P, Papworth L, Stafford C, Kohler GO, Livingston $A L$, Cheeke PR. Effect of alfalfa saponins on intestinal cholesterol absorption in rats. Am J Clin Nutr. 1977;30:2061-7.

14. Fiorucci S, Cipriani S, Mencarelli A, Renga B, Distrutti E, Baldelli F. Counterregulatory role of bile acid activated receptors in immunity and inflammation. Curr Mol Med. 2010;10:579-95.

15. Gadaleta RM, van Mil SWC, Oldenburg B, Siersema PD, Klomp LWJ, van Erpecum KJ. Bile acids and their nuclear receptor FXR: Relevance for hepatobiliary and gastrointestinal disease. Biochim Biophys Acta Mol Cell Biol Lip. 1801;2010:683-92.

16. Gadaleta RM, Oldenburg B, Willemsen ECL, Spit M, Murzilli S, Salvatore L, Klomp LWJ, Siersema PD, van Erpecum KJ, van Mil SWC. Activation of bile salt nuclear receptor FXR is repressed by pro-inflammatory cytokines activating NF-kappa B signaling in the intestine. Biochim Biophys Acta Mol Bas Dis. 1812;2011:851-8.

17. Gadaleta RM, van Erpecum KJ, Oldenburg B, Willemsen ECL, Renooij W, Murzilli S, Klomp LWJ, Siersema PD, Schipper MEI, Danese S, Penna G, Laverny G, Adorini L, Moschetta A, van Mil SWC. Farnesoid X receptor activation inhibits inflammation and preserves the intestinal barrier in inflammatory bowel disease. Gut. 2011;60:463-72.

18. Iwashita $Y$, Suzuki N, Yamamoto $T$, Shibata J, Isokawa $K$, Soon AH, Ikehata $Y$, Furuita H, Sugita T, Goto T. Supplemental effect of cholyltaurine and soybean lecithin to a soybean meal-based fish meal-free diet on hepatic and intestinal morphology of rainbow trout Oncorhynchus mykiss. Fish Sci. 2008;74:1083-95.

19. Iwashita Y, Suzuki N, Matsunari H, Sugita T, Yamamoto T. Influence of soya saponin, soya lectin, and cholyltaurine supplemented to a casein-based semipurified diet on intestinal morphology and biliary bile status in fingerling rainbow trout Oncorhynchus mykiss. Fish Sci. 2009;75:1307-15.

20. NRC. Nutrient requirements of fish and shrimp. Washington, D.C: The National Academies Press; 2011. p. 360.

21. Refstie S, Helland SJ, Storebakken T. Adaptation to soybean meal in diets for rainbow trout, Oncorhynchus mykiss. Aquaculture. 1997;153:263-72.

22. Schaffer R, Sniegoski LT, Welch MJ, White VE, Cohen A, Hertz HS, Mandel J, Paule RC, Svensson L, Bjorkhem I, Blomstrand R. Comparison of two isotope dilution/mass spectrometric methods for determination of total serum cholesterol. Clin Chem. 1982;28:5-8.

23. Tagliacozzi D, Mozzi AF, Casetta B, Bertucci P, Bernardini S, Di IC, Urbani A Federici G. Quantitative analysis of bile acids in human plasma by liquid chromatography-electrospray tandem mass spectrometry: a simple and rapid one-step method. Clin Chem Lab Med. 2003;41:1633-41.

24. Bjorkhem I, Falk O. Assay of the major bile acids in serum by isotope dilution-mass spectrometry. Scand J Clin Lab Invest. 1983;43:163-70.

25. Dzeletovic S, Breuer O, Lund E, Diczfalusy U. Determination of cholesterol oxidation-products in human plasma by isotope-dilution massspectrometry. Anal Biochem. 1995;225:73-80.

26. Acimovic J, Lovgren-Sandblom A, Monostory K, Rozman D, Golicnik M Lutjohann D, Bjorkhem I. Combined gas chromatographic/mass spectrometric analysis of cholesterol precursors and plant sterols in cultured cells. J Chromatogr B Anal Tech Biomed Life Sci. 2009;877:2081-6.

27. Lund E, Sisfontes L, Reihner E, Bjorkhem I. Determination of serum levels of unesterified lathosterol by isotope dilution-mass spectrometry. Scand J Clin Lab Invest. 1989:49:165-71.

28. Lovgren-Sandblom A, Heverin M, Larsson H, Lundstrom E, Wahren J, Diczfalusy U, Bjorkhem I. Novel LC-MS/MS method for assay of 7alphahydroxy-4-cholesten-3-one in human plasma. Evidence for a significant extrahepatic metabolism. J Chromatogr B Analyt Technol Biomed Life Sci. 2007;856:15-9.
29. Parini $P$, Johansson $L$, Broijersen $A$, Angelin B, Rudling M. Lipoprotein profiles in plasma and interstitial fluid analyzed with an automated gelfiltration system. Eur J Clin Invest. 2006;36:98-104.

30. van den Ingh TSGA, Krogdahl $\AA$, Olli JJ, Hendriks HGCJ, Koninkx JGJF. Effects of soybean-containing diets on the proximal and distal intestine in Atlantic Salmon (Salmo salar) - A Morphological-Study. Aquaculture. 1991;94:297-305.

31. Baeverfjord G, Krogdahl A. Development and regression of soybean meal induced enteritis in Atlantic salmon, Salmo salar $\mathrm{L}$, distal intestine: A comparison with the intestines of fasted fish. J Fish Dis. 1996;19:375-87.

32. Gatlin DM, Barrows FT, Brown P, Dabrowski K, Gaylord TG, Hardy RW, Herman E, Hu GS, Krogdahl Å, Nelson R, Overturf K, Rust M, Sealey W, Skonberg D, Souza EJ, Stone D, Wilson R, Wurtele E. Expanding the utilization of sustainable plant products in aquafeeds: a review. Aquaculture Res. 2007:38:551-79.

33. Naylor RL, Hardy RW, Bureau DP, Chiu A, Elliott M, Farrell AP, Forster I, Gatlin DM, Goldburg RJ, Hua K, Nichols PD. Feeding aquaculture in an era of finite resources. PNAS. 2009;106:15103-10.

34. Nordrum S, Bakke-McKellep AM, Krogdahl $\AA$, Buddington RK. Effects of soybean meal and salinity on intestinal transport of nutrients in Atlantic salmon (Salmo salar L.) and rainbow trout (Oncorhynchus mykiss). Comp Biochem Physiol B Biochem Mol Biol. 2000;125:317-35.

35. Lilleeng E, Froystad MK, Ostby GC, Valen EC, Krogdahl A. Effects of diets containing soybean meal on trypsin mRNA expression and activity in Atlantic salmon (Salmo salar L). Comp Biochem Physiol A Mol Int Physiol. 2007;147:25-36.

36. Penn MH, Bendiksen EA, Campbell P, Krogdahl Å. High level of dietary pea protein concentrate induces enteropathy in Atlantic salmon (Salmo salar L.). Aquaculture. 2011;310:267-73.

37. Krogdahl $\AA$, Penn M, Thorsen J, Refstie S, Bakke AM. Important antinutrients in plant feedstuffs for aquaculture: an update on recent findings regarding responses in salmonids. Aquaculture Res. 2010;41:333-44.

38. Stojancevic M, Stankov K, Mikov M. The impact of farnesoid X receptor activation on intestinal permeability in inflammatory bowel disease. Can J Gastroenterol. 2012;26:631-7.

39. Marjara IS, Chikwati EM, Valen EC, Krogdahl A, Bakke AM. Transcriptional regulation of IL-17A and other inflammatory markers during the development of soybean meal-induced enteropathy in the distal intestine of Atlantic salmon (Salmo salar L.). Cytokine. 2012;60:186-96.

40. Salze GP, Davis DA. Taurine: a critical nutrient for future fish feeds. Aquaculture. 2015;437:215-29.

41. Tocher DR, Bendiksen EA, Campbell PJ, Bell JG. The role of phospholipids in nutrition and metabolism of teleost fish. Aquaculture. 2008;280:21-34.

42. Kortner TM, Bjorkhem I, Krasnov A, Timmerhaus G, Krogdahl A. Dietary cholesterol supplementation to a plant-based diet suppresses the complete pathway of cholesterol synthesis and induces bile acid production in Atlantic salmon (Salmo salar L.). Br J Nutr. 2014;111:2089-103.

\section{Submit your next manuscript to BioMed Central and we will help you at every step:}

- We accept pre-submission inquiries

- Our selector tool helps you to find the most relevant journal

- We provide round the clock customer support

- Convenient online submission

- Thorough peer review

- Inclusion in PubMed and all major indexing services

- Maximum visibility for your research

Submit your manuscript at www.biomedcentral.com/submit
C) Biomed Central 